\title{
Bone marrow mesenchymal stem cells protect against retinal ganglion cell loss in aged rats with glaucoma
}

This article was published in the following Dove Press journal:

Clinical Interventions in Aging

30 October 2013

Number of times this article has been viewed

Ying $\mathrm{Hu}^{1,2}$

Hai Bo Tan'

Xin Mei Wang ${ }^{3}$

Hua Rong'

Hong Ping Cui'

$\mathrm{Hao} \mathrm{Cui}{ }^{2}$

Departments of Ophthalmology, 'Shanghai East Hospital of Tongji University, Shanghai, ${ }^{2}$ First Affiliated Hospital, ${ }^{3}$ Fourth Affiliated Hospital, Harbin Medical University, Harbin, People's Republic of China
Correspondence: Hao Cui Department of Ophthalmology, First Affiliated Hospital, Harbin Medical University, Harbin, People's Republic of China Email cuihao_eye@|63.com
Abstract: Glaucoma is a common eye disease in the aged population and has severe consequences. The present study examined the therapeutic effects of bone marrow mesenchymal stem cell (BMSC) transplantation in preventing loss of visual function in aged rats with glaucoma caused by laser-induced ocular hypertension. We found that BMSCs promoted survival of retinal ganglion cells in the transplanted eye as compared with the control eye. Further, in swimming tests guided by visual cues, the rats with a BMSC transplant performed significantly better. We believe that BMSC transplantation therapy is effective in treating aged rats with glaucoma.

Keywords: glaucoma, stem cell, transplantation, cell therapy, aging

\section{Introduction}

Glaucoma is a common eye disease in the aged population and has severe consequences..$^{1-3}$ Glaucoma leads to significant retina ganglion cell death and shrinkage of the optic nerve, as well as changes in visual areas within the brain. ${ }^{4,5}$ The cell death is irreversible and often leads to blindness. One of the best choices is stem cell transplantation, using progenitor cells or stem cells from different sources. ${ }^{6-8}$

Bone marrow mesenchymal stem cells (BMSCs) represent one of the best established stem cell lines, with well defined protocols for cell purification, amplification, and transplantation. ${ }^{6,9}$ Previous studies have demonstrated the usefulness of BMSCs in neuroprotection of retinal ganglion cells following different routes of transplantation. ${ }^{10-12}$ Here we generated a model of glaucoma in the aged rat, and investigated whether BMSCs lead to functional recovery. We found that BMSCs promoted survival of retinal ganglion cells in the transplanted eye as compared with the control eye. Further, in swimming tests guided by visual cues, the rats with BMSC transplants performed significantly better. We believe that BMSC transplantation therapy is effective in treating aged rats with glaucoma.

\section{Materials and methods Animal model}

This study was approved by the local ethics committee for animal research in the department of ophthalmology, First Affiliated Hospital, Harbin Medical University. Fifty aged male Sprague Dawley rats (aged 12-14 months) were sourced from the local animal center at Harbin Medical University and maintained on a 12/12 dark/light cycle with free access to food and water in single housing. 
Eight animals were used as the control group. For the animal model of glaucoma, the rats were anesthetized using a cocktail of ketamine $50 \mathrm{mg} / \mathrm{kg}$ and xylazine $10 \mathrm{mg} / \mathrm{kg}$. After the animals were settled, they were given $0.75 \mathrm{~W}$ pulses ( $50 \mu \mathrm{m}$ in diameter, 0.5 seconds) to both eyes from a $532 \mathrm{~nm}$ diode laser under the slit lamp. Aqueous outflow was blocked around the eye by approximately 50 laser pulses. One week later, the animals were retreated in order to achieve complete block of aqueous outflow.

\section{Intraocular pressure monitoring}

Intraocular pressure (IOP) was checked constantly for 24 hours after surgery, and every week thereafter. IOP was measured using a tonometer (Icare ${ }^{\circledR}$ Tonolab, TioLat, Helsinki, Finland). Only rats with clear IOP elevation (31 of 42 rats) were included and animals with variations were excluded from cell transplantation. Eleven rats were used as the surgical group and 20 rats were used for cell transplantation. The IOP before treatment was $20-25 \mathrm{mmHg}$, and increased by $7.9 \pm 2.1 \mathrm{mmHg}$ after treatment, which lasted for 3-4 days after treatment.

\section{BMSC transplantation}

BMSCs were purchased from Shanghai Shengong Biotechnology (Shanghai, People's Republic of China) and maintained in fetal bovine serum containing Dulbecco's modified Eagle's medium (Invitrogen, Shanghai, People's Republic of China). Six weeks after elevation of IOP, $3 \times 10^{4}$ (low) or $1 \times 10^{5}$ (high) BMSCs in $3 \mu \mathrm{L}$ of saline were transplanted into the vitreous cavity through the superior nasal retina of both eyes in the anesthetized rats. Blood supply was not disrupted in any of the animals.

\section{Fluorogold labeling for counting of retinal ganglion cells}

Fluorogold labeling was performed in the rat retina using superior colliculus retrograde labeling with $4 \mu \mathrm{L}$ of Fluorogold $5 \%$. One week later, the animals were sacrificed and perfused with $4 \%$ paraformaldehyde for retinal ganglion cell counting in retinal flatmounts. The cell count was performed in a double-blind manner by two independent investigators with experience in retina ganglion cell counting. Ten regions from each retina was randomly selected for cell counting. Seven animals from each group were used for this experiment.

\section{Visual water box performance}

We used the visual water box for examination of visual acuity as the species dependence of optometry (as shown in Figure 1).

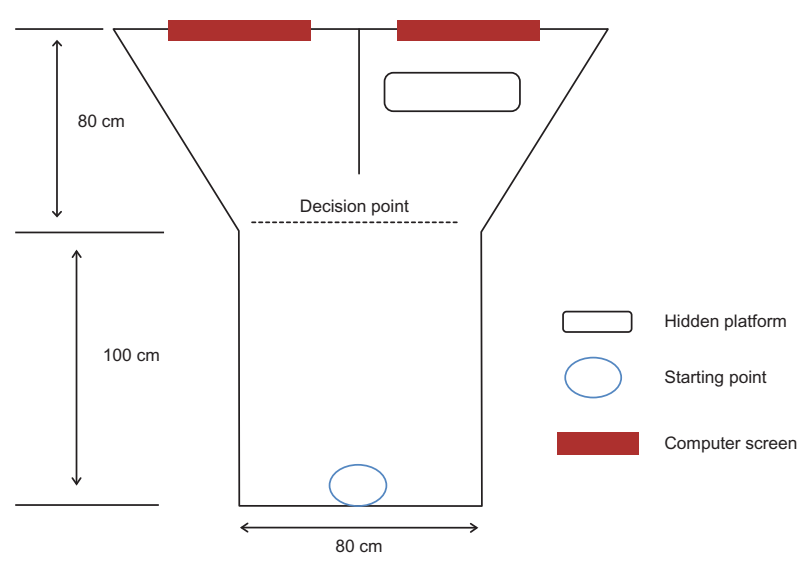

Figure I Design of the visual water box for behavior testing. The box was divided into three parts, ie, a swimming box and two decision chambers. A computer screen at the end of each decision chamber was used to present visual cues. In the right decision chamber, there was a hidden platform as the end point of the swimming test.

Four weeks after BMSC transplantation, the rats were trained to find the hidden platform at the end of the box using visual cues presented on a computer screen. This protocol has been well described in many previous reports.

\section{Statistical analysis}

The data were analyzed using the Statistical Package for the Social Sciences version 15.0 software (SPSS Inc, Chicago, IL, USA) and are presented as the mean \pm standard error. Group differences were determined by analysis of variance or paired $t$-tests. $P<0.05$ was determined as being statistically significant.

\section{Results \\ BMSC transplantation improved survival of retinal ganglion cells}

Ten weeks after surgery (4 weeks after BMSC transplantation), we counted the surviving retinal ganglion cells after the behavior tests. We found that IOP elevation led to severe retina ganglion cell loss $(P<0.01$, Figure 2B), and low numbers of transplanted cells were beneficial for survival of these cells (Figure 2C). In addition, high numbers of transplanted cells further enhanced cell survival (Figure 2D and Table 1).

\section{BMSC transplantation improved visual function}

The time latency to reach the hidden platform after 5 days of continuous training (three times per day). We found that glaucoma caused a significant loss of visual ability, which was 

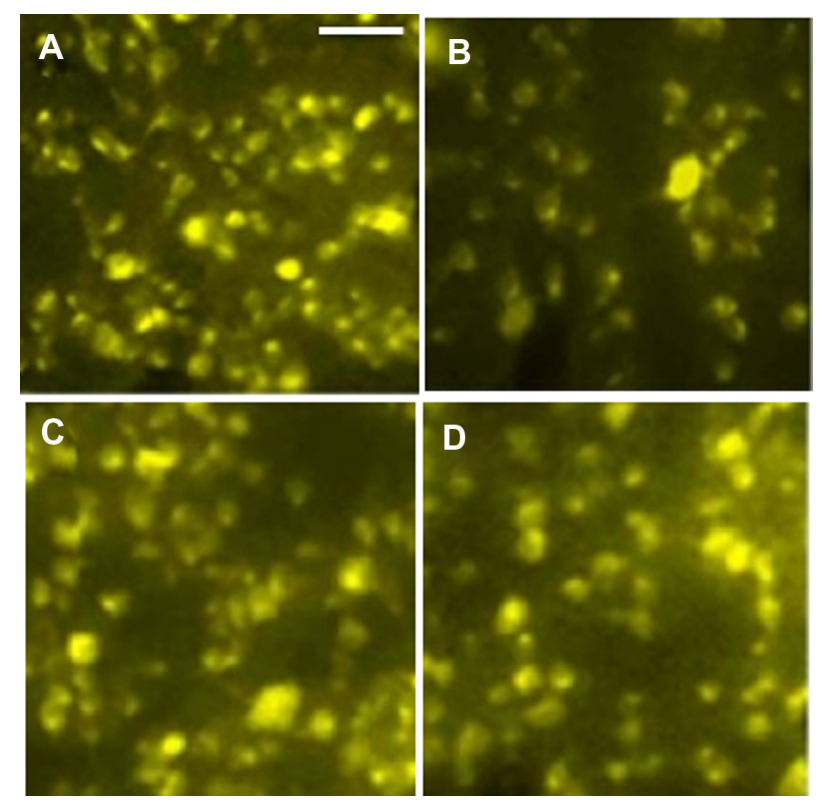

Figure 2 Fluorogold ${ }^{\circledR}$ counting of surviving retinal ganglion cells. (A) Control group, (B) surgery group, (C) low transplant group, and (D) high transplant group.

partly restored following both low number and high number BMSC transplantation $(P<0.05$ and $P<0.01$, respectively, Figure 3). However, in the high number transplantation group, the response was still significantly slower in comparison with the control group $(P<0.05)$, suggesting only partial rescue.

Correct arm responses were also correlated with BMSC transplantation (Table 2), with cell transplantation increasing the number of swimming trials using the correct arm.

\section{Discussion}

This study found that BMSC transplantation is protective in aged rats with retinal ganglion cell loss induced by glaucoma. Increased retinal ganglion cell survival is positively correlated with preservation of visual acuity 10 weeks after induction of glaucoma. All the animals were aged 14-17 months at the time of this experiment, so were representative of the

Table I BMSC transplantation improved RGC survival

\begin{tabular}{|c|c|c|}
\hline & $\mathrm{RGC} / \mathrm{mm}^{2}$ & Statistics \\
\hline Control group $(n=7)$ & $1800 \pm 101$ & \\
\hline Surgery group $(n=7)$ & $720 \pm 195$ & $\begin{array}{l}P<0.0 \text { I versus control } \\
\text { group }\end{array}$ \\
\hline $\begin{array}{l}\text { Low transplanted group } \\
(n=7)\end{array}$ & $1037 \pm 164$ & $\begin{array}{l}P<0.05 \text { versus control } \\
\text { and surgery groups }\end{array}$ \\
\hline $\begin{array}{l}\text { High transplanted group } \\
(\mathrm{n}=7)\end{array}$ & $1249 \pm 105$ & $\begin{array}{l}P<0.0 \text { I versus control } \\
\text { and surgery groups } \\
P<0.05 \text { versus low } \\
\text { transplant group }\end{array}$ \\
\hline
\end{tabular}

Abbreviations: BMSC, bone marrow mesenchymal stem cells; RGC, retina ganglion cells.

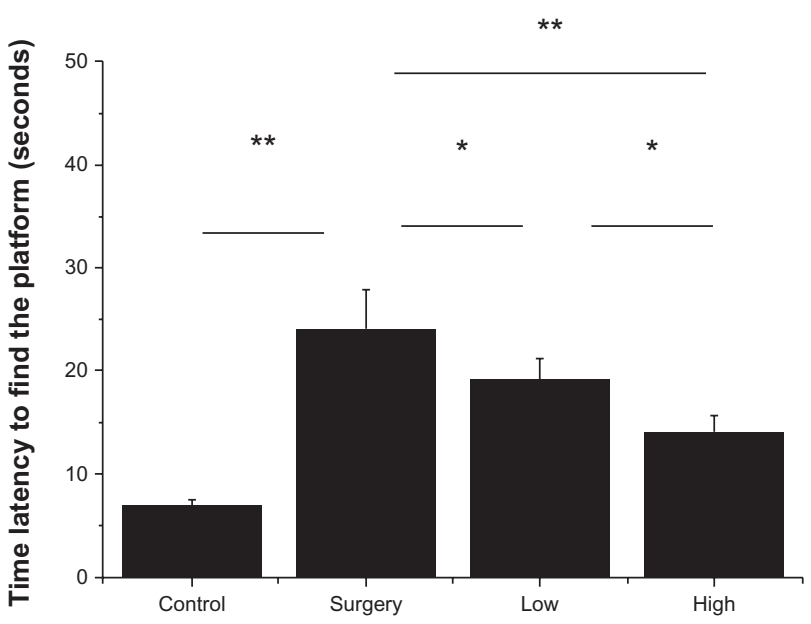

Figure 3 Results for visual water box swimming test, showing that the surgery group had a much slower response (longer latency to hidden platform) and that cell transplantation partly rescued this behavior.

Note: $*_{\text {indicates }} 0.05$; **indicates 0.01 .

aged population seen in clinical practice. We found no marked difference in setting up the glaucoma model in aged animals as compared with young rats aged 3-4 months. However, we do wish to point out that, based on our limited observations, the retinal ganglion cell loss was more severe (about 60\% death) compared to young animals after IOP elevation. This suggests that neuroprotective treatment as early as possible is critical to preserve more retinal ganglion cells because of the rapid loss of these ganglion cells in aged animals.

We examined cell transplantation with different numbers of BMSCs and we found that higher numbers of BMSCs improved visual function and retinal ganglion cell survival. Using a higher number of intergrated BMSCs, it is possible that the integrated cells increased and secreted more trophic factors for neuroprotection. We have yet to examine these integrated BMSCs by immunohistochemistry and cell tracing studies in order to provide evidence at the microscope level. In the future, it will be interesting to compare the BMSC

Table 2 BMSC transplantation improved swimming test guided by visual cues

\begin{tabular}{|c|c|c|}
\hline & $\begin{array}{l}\text { Percentage of } \\
\text { correct arm } \\
\text { swimming responses }\end{array}$ & Statistics \\
\hline Control group & $99.7 \%$ & \\
\hline Surgery group & $42.4 \%$ & $\begin{array}{l}P<0.0 \text { I versus } \\
\text { control group }\end{array}$ \\
\hline $\begin{array}{l}\text { Low transplanted } \\
\text { group }\end{array}$ & $67.5 \%$ & $\begin{array}{l}P<0.05 \text { versus control } \\
\text { and surgery groups }\end{array}$ \\
\hline $\begin{array}{l}\text { High transplanted } \\
\text { group }\end{array}$ & $88.3 \%$ & $\begin{array}{l}P<0.05 \text { versus control, } \\
\text { surgery, and low } \\
\text { transplant groups }\end{array}$ \\
\hline
\end{tabular}

Abbreviation: BMSC, bone marrow mesenchymal stem cells. 
survival differences in young and aged animals, in order to identify an appropriate stem cell transplantation protocol for the aged population.

\section{Author contributions}

Actually all authors participated in the design of the study while the details were made by YH, XW, HPC and HC. All the authors contributed toward data analysis, drafting and revising the article.

\section{Disclosure}

The authors report no conflicts of interest in this work.

\section{References}

1. Chrysostomou V, Rezania F, Trounce IA, Crowston JG. Oxidative stress and mitochondrial dysfunction in glaucoma. Curr Opin Pharmacol. 2013; 13(1):12-15.

2. Tataru CP, Purcarea VL. Antiglaucoma pharmacotherapy. J Med Life. 2012;5(3):247-251.

3. Thomas R. Glaucoma in developing countries. Indian J Ophthalmol. 2012;60(5):446-450.
4. Balaggan KS, Ali RR. Ocular gene delivery using lentiviral vectors. Gene Ther. 2012;19(2):145-153.

5. Wilson AM, Di Polo A. Gene therapy for retinal ganglion cell neuroprotection in glaucoma. Gene Ther. 2012;19(2):127-136.

6. Johnson TV, Martin KR. Cell transplantation approaches to retinal ganglion cell neuroprotection in glaucoma. Curr Opin Pharmacol. 2013;13(1):78-82.

7. Bouhenni RA, Dunmire J, Sewell A, Edward DP. Animal models of glaucoma. J Biomed Biotechnol. 2012;2012:692609.

8. Jindal N, Mukhopadhyay A, Anand A. The emerging role of stem cells in ocular neurodegeneration: hype or hope? Mol Cell Biochem. 2012; 365(1-2):65-76.

9. Johnson TV, Bull ND, Martin KR. Transplantation prospects for the inner retina. Eye. 2009;23(10):1980-1984.

10. Manuguerra-Gagne R, Boulos PR, Ammar A, et al. Transplantation of mesenchymal stem cells promotes tissue regeneration in a glaucoma model through laser-induced paracrine factor secretion and progenitor cell recruitment. Stem Cells. 2013;31:1136-1148.

11. Park HY, Kim JH, Sun Kim H, Park CK. Stem cell-based delivery of brain-derived neurotrophic factor gene in the rat retina. Brain Res. 2012;1469:10-23.

12. Johnson TV, Bull ND, Hunt DP, Marina N, Tomarev SI, Martin KR. Neuroprotective effects of intravitreal mesenchymal stem cell transplantation in experimental glaucoma. Invest Ophthalmol Vis Sci. 2010;51(4): 2051-2059.
Clinical Interventions in Aging

\section{Publish your work in this journal}

Clinical Interventions in Aging is an international, peer-reviewed journal focusing on evidence-based reports on the value or lack thereof of treatments intended to prevent or delay the onset of maladaptive correlates of aging in human beings. This journal is indexed on PubMed Central, MedLine, the American Chemical Society's 'Chemical Abstracts Ser-

\section{Dovepress}

vice' (CAS), Scopus and the Elsevier Bibliographic databases. The manuscript management system is completely online and includes a very quick and fair peer-review system, which is all easy to use. Visit $\mathrm{http}: / /$ www.dovepress.com/testimonials.php to read real quotes from published authors. 